\title{
Identification of synonyms and homonyms in grapevine cultivars (Vitis vinifera L.) from Asturias (Spain)
}

\author{
By P. MORENO-SANZ*, B. SUÁREZ and M. D. LOUREIRO \\ Regional Agrifood Research and Development Service (SERIDA), Food Technology Area, \\ P.O. Box 13, 33300 Villaviciosa, Asturias, Spain \\ (e-mail:paums@serida.org) \\ (Accepted 18 June 2008)
}

\begin{abstract}
SUMMARY
The abandonment of Asturian vineyards over the last century almost resulted in the extinction of the grapevine crop and major cultivar confusion. Due to the restoration of a number of these vineyards in recent years, research into the regional varietal stock is needed. The aims of the present study were to characterise genetic resources of Vitis vinifera L. in Asturias and to identify synonyms and homonyms through an analysis of six microsatellite markers: VVS2, VVMD5, VVMD7, VVMD27, VrZAG62, and VrZAG79. These markers are used internationally as recommended descriptors for the identification of grapevine cultivars and allow comparisons between laboratories. After PCR amplification of these microsatellite sequences, they were analysed by capillary electrophoresis. Forty-six accessions of $V$. vinifera L., corresponding to 14 cultivars, were analysed, but only nine different genotype profiles were found, due to synonyms for 'Albarín Tinto', 'Albarín Blanco' and 'Verdejo Tinto', and two homonyms for 'Albarín Blanco' being identified ('Godello' and 'Savagnin Blanc'). The most informative locus was VVMD5 and the least informative was VVMD27. The heterozygosity observed at all loci was higher than expected.
\end{abstract}

$\mathbf{V}^{\mathrm{i}}$ ineyards in Asturias (northern Spain) represent an ancient crop. References to grapevine (Vitis vinifera L.) cultivation have existed since the IXth century. In the middle of the XIXth century, grapevine cultivation covered 5,493 ha $(\mathrm{Feo}, 1986)$. This area was reduced to the present-day figure of 100 ha due to the growth of the mining industry in the mid-XXth century and migration of the rural population to the cities. Furthermore, the location of vineyards on steep slopes has made mechanisation and exploitation difficult, leading to reduced efficiency and low productivity.

A gradual reduction in mining activities since the 1980s has led people to reconsider viticulture as a possible economic resource. Accordingly, over the last 15 years, efforts have been made to restore Asturian vineyards. In 1997, establishment of the Cangas Winemakers Association (Asociación de Productores y Elaboradores de Vino de Cangas; APROVICAN) and official recognition of the region-specific wine appellation "Cangas Regional Wine" in 2001 (B.O.P.A., 2001) were important steps forward for this sector. Some old vineyards are now being pulled-up and replanted with cultivars endorsed by Cangas Regional Wine regulations such as: 'Albarín Negro' ('Albarín Tinto'), 'Carrasquín', 'Godello', 'Gewürztraminer', 'Merlot', 'Moscatel de Grano Menudo', 'Pinot Noir', and 'Syrah' (authorised) and 'Albarín Blanco', 'Albillo', 'Garnacha Tintorera', 'Mencía', 'Picapoli Blanco Extra', and 'Verdejo Negro' ('Verdejo Tinto') (recommended; B.O.P.A., 2007). This has resulted in a decrease in genetic diversity and loss of part of the local grapevine heritage.

*Author for correspondence.
Asturian vineyards are characterised by the presence of both autochthonous and allochthonous cultivars introduced by the French, who helped to restore the vineyards after an attack of phylloxera at the end of the XIXth century. Most of the cultivars grown in Asturias are considered to be minority cultivars (Cabello, 2004) which produce the lively, acidic, and aromatic wines characteristic of this region. Recognition of minority cultivars can be difficult due to the existence of synonyms and homonyms. Moreover, there is considerable inter- and intra-varietal diversity within and between vineyard plots, leading to further confusion.

Knowledge of Asturian varietal stock of $V$. vinifera $L$. is limited. Genetic erosion and the confusion of cultivars over time make it necessary to characterise and identify these cultivars again. An analysis of DNA microsatellite markers (SSRs) is the best method to achieve this aim compared with other methods such as ampelography (O.I.V., 1983), isozyme analysis (Subden et al., 1987; Royo et al., 1999; Cervera et al., 2001), RFLPs (Bowers et al., 1993), RAPDs (Vidal et al., 1999a, b), and/or AFLPs (Martínez-Zapater et al., 2000; Cervera et al., 2001). The high degree of polymorphism, co-dominant Mendelian inheritance, reproducibility, and ease of analysis of SSR markers (Thomas and Scott, 1993; Bowers et al., 1996; Sefc et al., 1999; Crespan and Milani, 2000) are characteristics that have made SSRs the method of choice for varietal identification in grapevine.

In this study, six SSR markers, proposed by the EU Project GENRES081 (http://www.genres.de/vitis), were analysed in 46 accessions of $V$. vinifera $\mathrm{L}$. collected in four boroughs in southwest Asturias, to establish synonyms and homonyms. 


\section{MATERIALS AND METHODS Plant material}

A total of 46 grapevine accessions were analysed, corresponding to 14 cultivars: 'Albarín Blanco', 'Albarín Francés', 'Albarín Negrín', 'Albarín Tinto', 'Albillo', 'Blanca del País', 'Blanco Verdín', 'Mencía', 'Mouratón', 'Tinta del País', 'Tinto Antiguo', 'Tinto Serodo', 'Verdejo Tinto', and 'Verdello Tinto'. Fresh young leaves were collected in the field from at least two vines of each cultivar, frozen, and preserved at $-80^{\circ} \mathrm{C}$. Samples were collected in four boroughs in southwest Asturias: Cangas del Narcea, Ibias, Illano, and Pesoz. The name of each cultivar was the one used by local growers. Four French ('Cabernet Sauvignon', 'Chardonnay', 'Merlot', and 'Pinot') and three national ('Godello', 'Mencía', and 'Merenzao') cultivars from the Subestación Enolóxica de Ribadumia (Xunta de Galicia, Spain) were also included as reference material.

\section{DNA extraction and quantification}

DNA was extracted from $65 \mathrm{mg}$ fresh leaf weight of each sample using the DNeasy ${ }^{\circledR}$ Plant Mini Kit (Qiagen, Hilden, Germany). The extracted DNA was quantified by electrophoresis in $1 \%(\mathrm{w} / \mathrm{v})$ agarose gels in $1 \mathrm{X}$ TAE buffer (0.04 M Tris-acetate, 0.001 M EDTA, pH 8.0). Gels were stained for $20 \mathrm{~min}$ in $2 \mu \mathrm{g} \mu \mathrm{l}^{-1}$ ethidium bromide in milliQ water, and visualised on an ultraviolet transilluminator. DNA was quantified using Gene Tools software (Syngene, Cambridge, UK) by comparison with known concentrations of $\lambda$ phage DNA (Bioron,

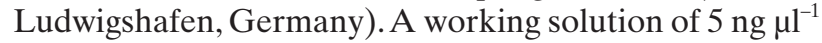
DNA was prepared for each sample.

\section{PCR amplification and microsatellite analysis}

A total of six SSR markers were used: VVS2 (Thomas and Scott, 1993); VVMD5 and VVMD7 (Bowers et al., 1996); VVMD27 (Bowers et al., 1999); and VrZAG62 and VrZAG79 (Sefc et al., 1999). One of the primers in each pair was labelled with a fluorochrome: 6-FAM (blue), VIC (green), or NED (yellow). As the size range of fragments amplified by primers labelled with the same fluorochrome did not overlap, we were able to analyse all six SSR markers simultaneously for each sample.

Two multiplex PCR reactions were carried out (Martín et al., 2003). PCR 1 contained the primers for VVS2, VVMD5, and VVMD7; and PCR 2 had the primers for VVMD27, VrZAG62, and VrZAG79. Both PCR reactions were performed in $12 \mu \mathrm{l}$ volumes containing $0.2 \mathrm{mM}$ each dNTP, $1.5 \mathrm{mM} \mathrm{MgCl}, 1$ Unit Tth DNA polymerase (Biotools, Madrid, Spain), $30 \mathrm{ng}$ template DNA, and $0.5 \mu \mathrm{M}$ VVS2, VVMD5, and 0.25 $\mu \mathrm{M}$ VVMD7 (PCR 1); or $0.5 \mu \mathrm{M}$ VrZAG79 and VVMD27 and 0.1 $\mu \mathrm{M}$ VrZAG62 (PCR 2). Amplification reactions were carried out in a GeneAmp ${ }^{\circledR}$ PCR System 9700 thermal cycler (Applied Biosystems, Langen, Germany) following the protocol described by Martín et al. (2003). We added a final extension step of $90 \mathrm{~min}$ at $65^{\circ} \mathrm{C}$ to favour the formation of $+\mathrm{A}$ alleles (Matsumoto et al., 2004).

Each PCR reaction was checked in a $3 \%(\mathrm{w} / \mathrm{v})$ agarose gel. The amplification products were diluted $(10-40$ fold) in sterile milliQ water, depending on the efficiency of amplification. Samples were analysed in an automated DNA sequencer (ABI PRISM ${ }^{\circledR}$ 3100; Applied
Biosystems) by the Sequencing Laboratory of the University of Oviedo, Asturias, Spain. Fluorescentlylabelled fragments were sized using Peak Scanner Software v.1.0 (Applied Biosystems). The internal standard used to assign sizes to the DNA fragments was GENESCAN500LIZ.

\section{Data analysis}

Several parameters were calculated from the different genotype profiles found. Genotypic frequencies (GF) were obtained by simple counting. Observed and expected heterozygosities $\left(H_{o}\right.$ and $H_{e}$, respectively) and allele frequencies (AF) were calculated using POPGENE32 software (http://www.ualberta.ca/ fyeh/ download.htm). The probability of null alleles $(r)$, the polymorphic information content (PIC), the discrimination power (D) and the probability of coincidence (C) of each locus, the cumulative discrimination power $\left(\mathrm{D}_{\mathrm{T}}\right)$ and the cumulative probability of coincidence $\left(\mathrm{C}_{\mathrm{T}}\right)$ were calculated according to the following formulae:

$r=\left(H_{e}-H_{o}\right) /\left(1+H_{e}\right)$ (Brookfield, 1996);

$\mathrm{PIC}=1-\Sigma p_{i}^{2}-\Sigma \Sigma 2 p_{i}^{2} p_{j}^{2}$ (Botstein et al., 1980); where $p_{i}$ and $p_{j}$ are the allele frequencies;

$\mathrm{D}=1-\mathrm{C}$, where $\mathrm{C}=\Sigma P_{i}^{2}$ and $P_{i}$ is the frequency of the different genotypes observed at a locus (Martín et al., 2003); and

$\mathrm{D}_{\mathrm{T}}=1-\mathrm{C}_{\mathrm{T}}$, where $\mathrm{C}_{\mathrm{T}}=\Pi \mathrm{C}_{\mathrm{m}}$ and $\Pi \mathrm{C}_{\mathrm{m}}$ is the cartesian product of the probability of coincidence of the six loci (Martín et al., 2003).

A presence-absence matrix was constructed using the allele values obtained for all accessions. The value " 1 " was assigned to the presence of a certain allele, and " 0 " to its absence. A cluster analysis was performed using NTSYS-PC v.2.2 software (Applied Biostatistics Inc., New York, USA). The SimQual module of this software was used to obtain the Jaccard's similarity matrix (Winzer et al., 2004). A dendrogram was obtained by the Unweighted Pair-Group Method with Arithmetic Averages (UPGMA). The co-phenetic correlation coefficient was calculated using the Coph and MxComp modules.

\section{RESULTS AND DISCUSSION}

The majority of vineyards around the World are planted with approx. $300-400$ cultivars in total. However, between 5,000 - 8,000 grapevine cultivars have been estimated to exist and be cultivated under 14,000 - 24,000 different names (Schneider et al., 2001). In recent years, local grapevine cultivars, which are grown marginally and are often endangered, are being characterised and conserved in germplasm banks as a future source of genetic diversity to preserve genes of agronomic and enological potential. Their cultivation is expanding slowly as a means to offer consumers different types of wine and to compete in the market. Local administrative organisations that control regionspecific wine appellations must therefore ensure that the cultivars used are only those that are legally accepted. It is important therefore to identify every grapevine cultivar as well as their synonyms and homonyms. 
TABLE I

Genetic profiles (allele sizes in bp), and codes according to GENRES 081, for the reference cultivars and the nine genotypes obtained at six SSR loci

\begin{tabular}{|c|c|c|c|c|c|c|}
\hline Cultivar & VVS2 & VVMD5 & VVMD7 & VVMD27 & VrZAG62 & VrZAG79 \\
\hline 'Cabernet Sauvignon' & $\begin{array}{c}\text { 134:147 } \\
\mathrm{n}+16:-\end{array}$ & $\begin{aligned} & 230: 238 \\
&-: n+18\end{aligned}$ & $\begin{array}{c}239: 239 \\
-:-\end{array}$ & $\begin{array}{c}\text { 171:185 } \\
\text { n:n+14 }\end{array}$ & $\begin{array}{c}186: 192 \\
-:-\end{array}$ & $\begin{array}{c}248: 248 \\
-:-\end{array}$ \\
\hline 'Chardonnay' & $\begin{array}{c}132: 138 \\
\mathrm{n}+14: \mathrm{n}+20\end{array}$ & $\begin{array}{c}232: 236 \\
\mathrm{n}+12: \mathrm{n}+16\end{array}$ & $\begin{aligned} 239 & : 243 \\
- & : n+12\end{aligned}$ & $\begin{array}{c}177: 185 \\
-:-\end{array}$ & $\begin{array}{c}186: 194 \\
n+14: n+22\end{array}$ & $\begin{array}{c}244: 246 \\
n+6: n+8\end{array}$ \\
\hline 'Merlot' & $\begin{array}{c}\text { 134:147 } \\
\mathrm{n}+16:-\end{array}$ & $\begin{array}{l}223: 234 \\
n+4: n+14\end{array}$ & $\begin{array}{l}239: 247 \\
n+8: n+16\end{array}$ & $\begin{array}{c}185: 187 \\
n+14: n+16\end{array}$ & $\begin{array}{c}192: 192 \\
n+20: n+20\end{array}$ & $\begin{array}{c}259: 259 \\
-:-\end{array}$ \\
\hline 'Pinot' & $\begin{array}{c}\text { 132:147 } \\
\mathrm{n}+14:-\end{array}$ & $\begin{array}{l}226: 236 \\
n+6: n+16\end{array}$ & $\begin{array}{l}239: 243 \\
n+8: n+12\end{array}$ & $\begin{array}{c}181: 185 \\
\mathrm{n}+10: \mathrm{n}+14\end{array}$ & $\begin{array}{c}186: 192 \\
n+14: n+20\end{array}$ & $\begin{array}{c}240: 246 \\
\mathrm{n}+2: \mathrm{n}+8\end{array}$ \\
\hline 'Mencía' & $\begin{array}{c}140: 147 \\
n+22: n+29\end{array}$ & $\begin{array}{l}223: 234 \\
n+3: n+14\end{array}$ & $\begin{array}{c}250: 257 \\
n+19: n+26\end{array}$ & $\begin{array}{l}177: 185 \\
n+6: n+14\end{array}$ & $\begin{array}{c}186: 192 \\
n+14: n+20\end{array}$ & $\begin{array}{c}248: 252 \\
n+10: n+14\end{array}$ \\
\hline 'Merenzao'/‘Verdejo Tinto' & $\begin{array}{c}138: 147 \\
n+20: n+29\end{array}$ & $\begin{array}{c}236: 236 \\
n+16: n+16\end{array}$ & $\begin{array}{l}239: 257 \\
n+8: n+26\end{array}$ & $\begin{array}{c}171: 185 \\
n: n+14\end{array}$ & $\begin{array}{c}186: 186 \\
n+14: n+14\end{array}$ & $\begin{array}{l}246: 248 \\
n+8: n+10\end{array}$ \\
\hline ‘Godello' ('Albarín Blanco')1 & $\begin{array}{c}147: 154 \\
n+29: n+36\end{array}$ & $\begin{array}{l}223: 236 \\
n+3: n+16\end{array}$ & $\begin{array}{l}239: 243 \\
n+8: n+12\end{array}$ & $\begin{array}{c}181: 185 \\
n+10: n+14\end{array}$ & $\begin{array}{c}184: 186 \\
n+12: n+14\end{array}$ & $\begin{array}{c}252: 252 \\
\mathrm{n}+14: \mathrm{n}+14\end{array}$ \\
\hline 'Albarín Blanco' & $\begin{array}{c}128: 147 \\
n+10: n+29\end{array}$ & $\begin{array}{l}219: 236 \\
n-1: n+16\end{array}$ & $\begin{array}{l}239: 257 \\
n+8: n+26\end{array}$ & $\begin{array}{l}177: 185 \\
n+6: n+14\end{array}$ & $\begin{array}{c}184: 192 \\
n+12: n+20\end{array}$ & $\begin{array}{l}246: 248 \\
\mathrm{n}+8: \mathrm{n}+10\end{array}$ \\
\hline 'Savagnin Blanc' ('Albarín Blanco') & $\begin{array}{c}147: 147 \\
\mathrm{n}+29: \mathrm{n}+29\end{array}$ & $\begin{array}{c}230: 236 \\
\mathrm{n}+10: \mathrm{n}+16\end{array}$ & $\begin{array}{c}243: 257 \\
n+12: n+26\end{array}$ & $\begin{array}{c}185: 185 \\
\mathrm{n}+14: \mathrm{n}+14\end{array}$ & $\begin{array}{c}186: 192 \\
n+14: n+20\end{array}$ & $\begin{array}{l}246: 252 \\
n+8: n+14\end{array}$ \\
\hline 'Albillo' & $\begin{array}{c}128: 138 \\
n+10: n+20\end{array}$ & $\begin{array}{l}226: 234 \\
n+6: n+14\end{array}$ & $\begin{array}{l}239: 247 \\
\mathrm{n}+8: \mathrm{n}+16\end{array}$ & $\begin{array}{c}181: 185 \\
\mathrm{n}+10: \mathrm{n}+14\end{array}$ & $\begin{array}{c}192: 202 \\
n+20: n+30\end{array}$ & $\begin{array}{l}252 *: 259 \\
\mathrm{n}+14: \mathrm{n}+21\end{array}$ \\
\hline 'Mouratón' & $\begin{array}{c}132: 147 \\
n+14: n+29\end{array}$ & $\begin{array}{c}232: 236 \\
\mathrm{n}+12: \mathrm{n}+16\end{array}$ & $\begin{array}{c}250: 257 \\
n+19: n+26\end{array}$ & $\begin{array}{l}\text { 177:185 } \\
\mathrm{n}+6: \mathrm{n}+14\end{array}$ & $\begin{array}{c}186: 202 \\
n+14: n+30\end{array}$ & $\begin{array}{c}248: 252 \\
n+10: n+14\end{array}$ \\
\hline 'Albarín Tinto' & $\begin{array}{c}138: 147 \\
n+20: n+29\end{array}$ & $\begin{array}{l}223: 236 \\
n+3: n+16\end{array}$ & $\begin{array}{c}253: 257 \\
n+22: n+26\end{array}$ & $\begin{array}{l}175: 185 \\
n+4: n+14\end{array}$ & $\begin{array}{c}186: 198 \\
n+14: n+26\end{array}$ & $\begin{array}{c}252: 252 \\
\mathrm{n}+14: \mathrm{n}+14\end{array}$ \\
\hline Unknown (Verdello T.-Pesoz) ${ }^{1}$ & $\begin{array}{c}128: 138 \\
\mathrm{n}+10: \mathrm{n}+20\end{array}$ & $\begin{array}{c}232: 232 \\
\mathrm{n}+12: \mathrm{n}+12\end{array}$ & $\begin{array}{l}239: 243 \\
\mathrm{n}+8: \mathrm{n}+12\end{array}$ & $\begin{array}{l}177: 190 \\
n+6: n+19\end{array}$ & $\begin{array}{c}186: 194 \\
n+14: n+22\end{array}$ & $\begin{array}{l}244: 257 \\
\mathrm{n}+6: \mathrm{n}+19\end{array}$ \\
\hline
\end{tabular}

The - symbol indicates that no code was assigned to that allele by the GENRES081 Project. The shortest allele found, for each marker, within this Project was chosen arbitrarily as being " $n$ ". The size codes are then given relative to " $n$ ".

*Allele peak much less intense than the major allele.

Cultivar names erroneously provided by the growers.

Viticulture in Asturias is longstanding, but the abandonment of vineyards in the XXth century has led to confusion regarding cultivar identity. The recovery of this crop, based mainly on autochthonous cultivars such as 'Albarín Blanco', 'Albarín Tinto', 'Carrasquín', and 'Verdejo Tinto', and the recent recognition of the Cangas Regional Wine appellation in 2001 (B.O.P.A., 2001) has further highlighted this problem. Mis-naming in the region leads to inaccuracy in vegetative propagation for new plantations, spreading this problem to new growing areas.
Possible synonyms and homonyms were observed in previous ampelographic studies, and microsatellite DNA analysis were carried out to confirm these data (Santiago et al., 2005; Crespan et al., 2006).

The allele size data obtained were transformed into a code (Table I), to make them comparable with data from other laboratories (This et al., 2004), according to the method proposed by the GENRES081 Project. In this study, we included some of the reference cultivars required for the correct application of this method (e.g., 'Cabernet Sauvignon', 'Chardonnay', 'Merlot', and

TABLE II

Allele sizes $(A S)$ in bp and allele frequencies $(A F)$ for the six SSR markers in the nine grapevine genotypes discriminated in this study

\begin{tabular}{|c|c|c|c|c|c|c|c|c|c|c|c|c|}
\hline \multirow[b]{2}{*}{ Allele } & \multicolumn{2}{|c|}{ VVS2 } & \multicolumn{2}{|c|}{ VVMD5 } & \multicolumn{2}{|c|}{ VVMD7 } & \multicolumn{2}{|c|}{ VVMD27 } & \multicolumn{2}{|c|}{ VrZAG62 } & \multicolumn{2}{|c|}{ VrZAG79 } \\
\hline & AS & $\mathrm{AF}$ & AS & $\mathrm{AF}$ & AS & $\mathrm{AF}$ & AS & $\mathrm{AF}$ & AS & $\mathrm{AF}$ & AS & $\mathrm{AF}$ \\
\hline $\mathrm{A}$ & 128 & 0.167 & 219 & 0.056 & 239 & 0.278 & 171 & 0.056 & 184 & 0.111 & 244 & 0.056 \\
\hline B & 132 & 0.056 & 223 & 0.167 & 243 & 0.167 & 175 & 0.056 & 186 & 0.444 & 246 & 0.167 \\
\hline $\mathrm{C}$ & 138 & 0.222 & 226 & 0.056 & 247 & 0.056 & 177 & 0.222 & 192 & 0.222 & 248 & 0.222 \\
\hline $\mathrm{D}$ & 140 & 0.056 & 230 & 0.056 & 250 & 0.111 & 181 & 0.111 & 194 & 0.056 & 252 & 0.444 \\
\hline E & 147 & 0.444 & 232 & 0.167 & 253 & 0.056 & 185 & 0.500 & 198 & 0.056 & 257 & 0.056 \\
\hline $\mathrm{F}$ & 154 & 0.056 & 234 & 0.111 & 257 & 0.333 & 190 & 0.056 & 202 & 0.111 & 259 & 0.056 \\
\hline G & - & - & 236 & 0.389 & - & - & - & - & - & - & - & - \\
\hline
\end{tabular}

TABLE III

Observed genotypes $(O G)$ and genotypic frequencies $(G F)$ for each SSR marker in the nine grapevine genotypes discriminated in this study

\begin{tabular}{|c|c|c|c|c|c|c|c|c|c|c|c|}
\hline \multicolumn{2}{|c|}{ VVS2 } & \multicolumn{2}{|c|}{ VVMD5 } & \multicolumn{2}{|c|}{ VVMD7 } & \multicolumn{2}{|c|}{ VVMD27 } & \multicolumn{2}{|c|}{ VrZAG62 } & \multicolumn{2}{|c|}{ VrZAG79 } \\
\hline $\mathrm{OG}^{\dagger}$ & GF & OG & GF & OG & GF & $\mathrm{OG}$ & GF & $\mathrm{OG}$ & GF & OG & GF \\
\hline $\mathrm{AC}$ & 0.222 & AG & 0.111 & $\mathrm{AB}$ & 0.222 & $\mathrm{AE}$ & 0.111 & $A B$ & 0.111 & $\mathrm{AE}$ & 0.111 \\
\hline $\mathrm{AE}$ & 0.111 & $\mathrm{BF}$ & 0.111 & $\mathrm{AC}$ & 0.111 & $\mathrm{BE}$ & 0.111 & $\mathrm{AC}$ & 0.111 & $\mathrm{BC}$ & 0.222 \\
\hline $\mathrm{BE}$ & 0.111 & BG & 0.222 & $\mathrm{AF}$ & 0.222 & $\mathrm{CE}$ & 0.333 & $\mathrm{BB}$ & 0.111 & BD & 0.111 \\
\hline $\mathrm{CE}$ & 0.222 & CF & 0.111 & BF & 0.111 & $\mathrm{CF}$ & 0.111 & BC & 0.222 & CD & 0.222 \\
\hline $\mathrm{DE}$ & 0.111 & DG & 0.111 & DF & 0.222 & DE & 0.222 & $\mathrm{BD}$ & 0.111 & DD & 0.222 \\
\hline $\mathrm{EE}$ & 0.111 & $\mathrm{EE}$ & 0.111 & $\mathrm{EF}$ & 0.111 & $\mathrm{EE}$ & 0.111 & $\mathrm{BE}$ & 0.111 & $\mathrm{DF}$ & 0.111 \\
\hline $\mathrm{EF}$ & 0.111 & $\mathrm{EG}$ & 0.111 & & & & & $\mathrm{BF}$ & 0.111 & & \\
\hline & & GG & 0.111 & & & & & $\mathrm{CF}$ & 0.111 & & \\
\hline
\end{tabular}

The genotype letter code corresponds to combinations of the allele letter code in Table II. 
TABLE IV

Number of observed alleles $(N A)$, observed heterozygosity $\left(\mathrm{H}_{\mathrm{o}}\right)$, expected heterozygosity $\left(\mathrm{H}_{\mathrm{e}}\right)$, null allele probability $(\mathrm{r})$, probability of coincidence $(C)$, discrimination power $(D)$ and polymorphic information content (PIC) of the six SSR markers in the nine grapevine genotypes discriminated in this study

\begin{tabular}{|c|c|c|c|c|c|c|c|}
\hline Locus & NA & $H_{o}$ & $H_{e}$ & $r$ & $\mathrm{C}$ & $\mathrm{D}$ & PIC \\
\hline VVS2 & 6 & 0.889 & 0.716 & -0.101 & 0.160 & 0.840 & 0.678 \\
\hline VVMD5 & 7 & 0.778 & 0.772 & -0.003 & 0.136 & 0.864 & 0.744 \\
\hline VVMD7 & 6 & 1.000 & 0.765 & -0.133 & 0.185 & 0.815 & 0.730 \\
\hline VVMD27 & 6 & 0.889 & 0.679 & -0.125 & 0.210 & 0.790 & 0.641 \\
\hline VrZAG62 & 6 & 0.889 & 0.722 & -0.097 & 0.136 & 0.864 & 0.687 \\
\hline VrZAG79 & 6 & 0.778 & 0.716 & -0.036 & 0.185 & 0.815 & 0.678 \\
\hline Mean & - & 0.870 & 0.728 & - & - & - & - \\
\hline Cumulative & 37 & - & - & - & $2.1 \times 10^{-5}$ & 0.999979 & - \\
\hline
\end{tabular}

'Pinot'). 'Godello', Mencía', and 'Merenzao' were analysed in order to establish synonyms and homonyms, and to check whether 'Mencía' in Asturias corresponded to 'Mencía' grown in other regions of Spain.

All six microsatellite loci showed polymorphism. The number of alleles at each locus varied from six (VVS2, VVMD7, VVMD27, VrZAG62, and VrZAG79) to seven (VVMD5), with a total of 37 alleles. The most common alleles, with allele frequencies greater than $40 \%$, were VVS2-147, VVMD27-185, VrZAG62-186, and VrZAG79252 (Table II). Martín et al. (2003) studied 176 accessions from the Vitis Germplasm Bank at El Encín, and also found allele VrZAG62-186 to be one of the most frequent (sized by them at $187 \mathrm{bp}$ ).

The number of different genotypes observed per locus varied between six for VVMD7, VVMD27 and VrZAG79, to eight for VVMD5 and VrZAG62 (Table III). The most frequent genotype was $177 / 185$ (VVMD27), with a frequency of 33.3\%. Analysis of all 46 accessions allowed the identification of nine different genotypes (Table I).

$H_{o}$ ranged between $77.8 \%$ (VVMD5 and VrZAG79) and $100 \%$ (VVMD7), with a mean value of $87.0 \% . H_{e}$ ranged between $67.9 \%$ (VVMD27) and $77.2 \%$ (VVMD5), with a mean value of $72.8 \%$ (Table IV). $H_{o}$ was greater than $H_{e}$ at all loci. Loci where a single allele was detected were considered to be homozygotes rather than heterozygotes with a null allele, which could lead to an overestimation of homozygosity and an underestimation of heterozygosity values. The probability of null alleles for all loci was negative. The high $H_{o}$ values may be a consequence of both natural and human selection against homozygosity in grapevine plants (Sefc et al., 2001).

PIC assesses the usefulness of different microsatellite markers for reliable cultivar distinction in grapevine. The most informative locus was VVMD5 $(\mathrm{PIC}=0.744)$. The least informative marker, with a PIC of 0.641 , was VVMD27 (Table IV).

Discrimination power (D) estimates the probability that two cultivars, selected by chance, can be distinguished by their profile at a given locus, or at all loci analysed in the case of cumulative values. VVMD5 and VrZAG62 showed the highest discrimination power $(\mathrm{D}=0.864)$, and VVMD27 presented the lowest $(\mathrm{D}=$ $0.790)$. The cumulative discrimination power was almost $1\left(\mathrm{D}_{\mathrm{T}}=0.999979\right)$. This means that, combining all six loci, there was a 2 in $10^{5}$ chance $\left(\mathrm{C}_{\mathrm{T}}=2.1 \times 10^{-5}\right)$ that two cultivars, selected at random from a set with the same allele and genotype frequencies which we obtained, would have identical genotypes at all loci. This probability is higher than that obtained by Martín et al. $\left(2003 ; \mathrm{C}_{\mathrm{T}}=0.11 \times 10^{-7}\right.$ in a study of 163 cultivars $)$,

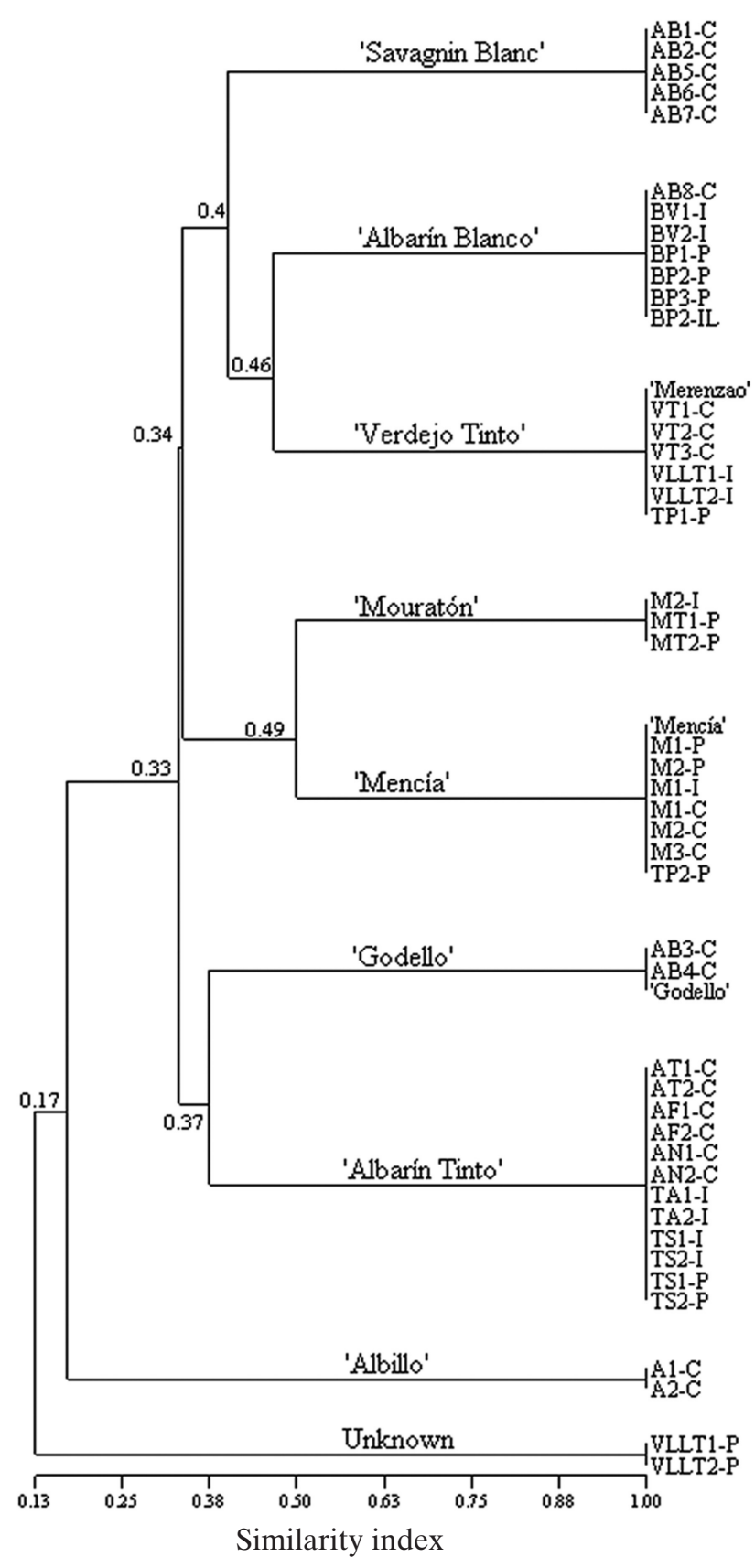

FIG. 1

Dendrogram of the nine identified genotypes generated by applying the UPGMA method using the Jaccard coefficient matrix. Accessions abbreviations: first letters corresponds to the cultivar 'Albarín Blanco' (AB); 'Albarín Francés' (AF); 'Albarín Negrín' (AN); 'Albarín Tinto' (AT); 'Albillo' (A); 'Blanca del País' (BP); 'Blanco Verdín' (BV); 'Mencía' (M); 'Mouratón' (MT); 'Tinto Antiguo' (TA); 'Tinta del País' (TP); 'Tinto Serodo' (TS), 'Verdejo Tinto' (VT), and 'Verdello Tinto' (VLLT), the following number indicates the accession number, and the letter after the hyphen indicates the borough of origin [Cangas del Narcea (C), Ibias (I), Illano (IL) and Pesoz (P)]. 
probably due to the greater diversity of germplasm analysed by these authors.

The dendrogram obtained from the Jaccard's similarity matrix is shown in Figure 1. The co-phenetic correlation coefficient was 0.98 , a good fit to the original similarity matrix. The dendrogram showed nine groups:

'Mencía': All accessions showed the same microsatellite profile as 'Mencía' grown in other regions of Spain, except one from the borough of Ibias (M2-I), which matched with 'Mouratón'.

'Mouratón': All accessions matched with the 'Mouratón' from the Germplasm Bank at El Encín, Madrid (Martín et al., 2003).

'Albarin Tinto': The following synonyms of this cultivar were found: 'Albarín Negrín', 'Albarín Francés', 'Tinto Serodo', and 'Tinto Antiguo'. We found very few 'Albarín Francés' vines. Martínez and Pérez (1999) considered 'Albarín Tinto' and 'Albarín Francés' to be different cultivars on the basis of ampelographic descriptions. We shall continue to survey the region for more 'Albarín Francés' vines and increase the number of microsatellite markers to analyse both cultivars to confirm this synonym.

'Albarín Blanco': Two different genotypes corresponding to this name were found by Santiago et al. (2005) in Cangas del Narcea. One was considered to be the true 'Albarín Blanco', and the other was identified as 'Savagnin Blanc'. Ampelographic variability was observed for the accessions we collected. Microsatellite analysis showed three different profiles, which matched with 'Godello' from Galicia, 'Savagnin Blanc', and the true 'Albarín Blanco'. Hence, 'Godello' can be considered to be another homonym of this cultivar. Accessions of 'Blanco Verdín' from Ibias, and 'Blanca del País' collected in Pesoz and Illano, were synonyms of the true 'Albarín Blanco'.
'Verdejo Tinto': Accessions of 'Verdejo Tinto', 'Verdello Tinto' (from Ibias), and 'Merenzao' showed the same microsatellite profile. 'Verdello Tinto' from $\mathrm{Pesoz}$ presented a different profile, not yet identified. In fact, strong ampelographic differences were found between the accessions from Pesoz and Ibias.

'Albillo': Suárez (1879) considered this cultivar to be a synonym of 'Albarín Blanco', but they are different cultivars, as pointed out in a previous ampelographic study (Martínez and Pérez, 1999). When comparing databases, 'Albillo' accessions matched with 'Temprano Blanco' ('Chasselas Doré') from the Germplasm Bank at El Encín (Martín et al., 2003).

'Tinta del País': These accessions were incorrectly identified by the vine grower. We identified one as 'Mencía' and the other as 'Verdejo Tinto'. We found just two vines of 'Tinta del País' in all the plots sampled. We aim to increase the area surveyed, to try to locate more 'Tinta del País' vines.

This work represents an important step in increasing our knowledge of grapevine cultivars from Asturias, and helps to control the use of cultivars included in the Cangas Regional Wine regulations. The establishment of synonyms and homonyms will thus allow a broader surveillance of genetic resources of the cultivars 'Albarín Tinto' and 'Verdejo Tinto', and correct identification of 'Albarín Blanco', which are currently undergoing clonal selection.

This research was supported by FICYT Project IB05159. M.D. Loureiro and P. Moreno-Sanz were funded by the Instituto Nacional de Investigación y Tecnología Agraria y Alimentaria, INIA (Ministry of Agriculture, Spain). We wish to thank the Subestación Enolóxica of Ribadumia for providing the reference plants, Nuria Cid Álvarez and Dr. José Luis Martínez Fernández for their technical support, Dr. Anna Picinelli Lobo for help with the drafting of the paper, as well as the grapevine growers.

\section{REFERENCES}

Boletín Oficial del Principado de Asturias. (2001). Resolución de 25 de Mayo de 2001, de la Consejería de Medio Rural y Pesca (B.O.P.A. $\left.n^{\circ} 132,08 / 06 / 2001\right) .7805-7807$.

Boletín Oficial del Principado de Asturias. (2007). Resolución de 19 de Diciembre de 2006, de la Consejería de Medio Rural y Pesca (B.O.P.A. no 5, 08/01/2007). 306-307.

Botstein, D., White, R. L., Skolnick, M. and Davis, R. W. (1980). Construction of a genetic linkage map in man using restriction fragment length polymorphisms. American Journal of Human Genetics, 32, 314-331.

Bowers, J. E., Bandman, E. B. and Meredith, C. P. (1993). DNA fingerprint characterization of some wine grape cultivars. American Journal of Enology and Viticulture, 44, 266-274.

Bowers, J. E., Dangl, G. S., Vignani, R. and Meredith, C. P. (1996). Isolation and characterization of new polymorphic simple sequence repeat loci in grape (Vitis vinifera L.). Genome, 39, 628-633.

Bowers, J. E., Dangl, G. S. and Meredith, C. P. (1999). Development and characterization of additional microsatellite DNA markers for grape. American Journal of Enology and Viticulture, 50, 243-246.
Brookfield, J. F. Y. (1996). A simple new method for estimating null allele frequency from heterozygote deficiency. Molecular Ecology, 5, 453-455.

Cabello, F. (2004). Situación del Patrimonio Varietal de la Especie Vitis vinifera $L$. Available via the Web: $<$ http://www.acenologia.com/ ciencia67 02.htm>.

Cervera, M. T., Rodriguez, I., Cabezas, J. A., Chavez, J., Martínez-Zapater, J. M. and CABello, F. (2001). Morphological and molecular characterization of grapevine accessions known as Albillo. American Journal of Enology and Viticulture, 52, 127-135.

Crespan, M. and Milani, N. (2000). Application of various molecular methodologies to the characterization of rootstocks and table grapevines. Proceedings of the VIIth International Symposium on Grapevine Genetics and Breeding, Montpellier, France. 1998. (Bouquet, A. and Boursiquot, J. M., Eds.). Volume 1, 97-104.

Crespan, M., Cabello, F., Giannetto, S., ibáñez, J., Karoglan Kontic, J., Maletic, E., Pejic, I., Rodríguez-Torres, I. and Antonacci, D. (2006). 'Malvasia delle Lipari', 'Malvasia de Sardegna', 'Greco di Gerace', 'Malvasia de Sitges' and 'Malvasia dubrovaãka' - synonyms of an old and famous cultivar. Vitis, 45, 69-73. 
FEO, F. (1986). El viñedo en Asturias: cultivo marginal en vías de extinción. Boletín del Real Instituto de Estudios Asturianos, 40, 589-610.

Martín, J. P., Borrego, J., Cabello, F. and Ortiz, J. M. (2003). Characterization of Spanish grapevine cultivar diversity using sequence-tagged microsatellite site markers. Genome, 46, 10-18.

Martínez, M. C. and Pérez, J. E. (1999). La vid en el occidente del Principado de Asturias: descripción ampelográfica de las variedades. Consejo Superior de Investigaciones Científicas (CSIC), Madrid, Spain. 101 pp.

Martínez-Zapater, J. M. Cabezas, J. A. and Cervera, M. T. (2000). AFLPs in genetic identification and genome analysis of grapevines. Proceedings of the VIIth International Symposium on Grapevine Genetics and Breeding, Montpellier, France. 1998. (Bouquet, A. and Boursiquot, J. M., Eds.). Volume 1, 105-110.

Matsumoto, T., Yukawa, W., Nozaki, Y., Nakashige, R., Shinya, M., Makino, S., Yagura, M., IKuta, T., Imanishi, T., InOKO, H., TAMIYA, G. and GoJobori, T. (2004). Novel algorithm for automated genotyping of microsatellites. Nucleic Acids Research,32, 6069-6077.

O.I.V. (1983). Código de los Caracteres Descriptivos de las Variedades y Especies de Vitis. Organisation Internationale de la Vigne et du Vin. Available via the Web: <http://news.reseau-concept.net/ images/oiv/Client/Caracteres_ampelographiques.pdf $>$.

Royo, J. B., Miranda, S., GonzÁlez, J. and Itoiz, R. (1999). Isoenzimas en la identificación varietal de vid: metodología y muestreo. Jornadas de Agronomía: Identificación Molecular de Germoplasma de Vid. Madrid, Spain. 1998. Fundación Premio Arce and IMIA. 75-80.

Santiago, J., Boso, S., Vilanova, M. and Martínez, M. C. (2005). Characterization of cv. Albarín Blanco (Vitis vinifera L.). Synonyms, homonyms and errors of identification associated with this cultivar. Journal International des Sciences de la Vigne et du Vin, 39, 57-65.

Schneider, A., Carra, A., Akkak, A., This, P., Laucou, V. and BоттA, R. (2001). Verifying synonymies between grape cultivars from France and Northwestern Italy using molecular markers. Vitis, 40, 197-203.
Sefc, K. M., Regner, F., Turetschek, E., Glössl, J. and STEINKELlNER, H. (1999). Identification of microsatellite sequences in Vitis riparia and their applicability for genotyping of different Vitis species. Genome, 42, 1-7.

Sefc, K. M., Lefort, F., Grando, M. S., Scott, K. D., Steinkellner, H. and Thomas, M. R. (2001). Microsatellite markers for grapevine: a state of the art. In: Molecular Biology and Biotechnology of Grapevine. (Roubelakis-Angelakis, K.A., Ed.). Kluwer Academic Publishers, Dordrecht, The Netherlands. 433-464.

SuÁrez, N. (1879). Breves apuntes sobre el vino de Cangas de Tineo. Revista de Asturias, 3, 219-221.

Subden, R. E., Krizus, A., Lougheed, S. C. and Carey, K. (1987). Isozyme characterization of Vitis species and some cultivars. American Journal of Enology and Viticulture, 38, 176-181.

This, P., Jung, A., Boccaci, P., Borrego, J., Botta, R., Costantini, L., Crespan, M., Dangl, G. S., Eisenheld, C., FerreiraMonteiro, F., Grando, S., IbÁÑez, J., LACOMbe, T., LAucou, V., Magalhanes, R., Meredith, C. P., Milani, N., Peterlunger, E., Regner, F., Zukini, L. and Maul, E. (2004). Development of a standard set of microsatellite reference alleles for identification of grape cultivars. Theoretical and Applied Genetics, 109, $1448-1458$.

Thomas, M. R. and ScotT, N. S. (1993). Microsatellite repeats in grapevine reveal DNA polymorphisms when analysed as sequence-tagged sites (STSs). Theoretical and Applied Genetics, 86, 985-990.

Vidal, J. R., CoArer, M. and Defontaine, A. (1999a). Genetic relationships among grapevine varieties grown in different French and Spanish regions based on RAPD markers. Euphytica, 109, 161-172.

Vidal, J. R., Moreno, S., Gogorcena, Y., Masa, A. and Ortiz, J. M. (1999b). On the genetic relationships and origins of six grape cultivars of Galicia (Spain) using RAPD markers. American Journal of Enology and Viticulture, 50, 69-75.

Winzer, N., Di Renzo, M. and Olmos, S. (2004). Métodos para estimar variabilidad genética. In: Biotecnología y Mejoramiento Vegetal. INTA-Instituto Nacional de Tecnología Agropecuaria, Buenos Aires, Argentina. 199-210. 